\title{
IMPLEMENTASI PROGRAM POLISI SEKOLAH SEBAGAI BEST PRACTICE UNTUK MENINGKATKAN KEDISIPLINAN SISWA
}

\author{
Sri Isnani \\ SMP Negeri 02 Arjasa Jember \\ Email : itsnania@gmail.com
}

\begin{abstract}
Abstrak
Kedisiplinan di sekolah dapat ditingkatkan melalui pendidikan karakter, salah satunya dengan menerapkan program Polisi Sekolah. Penelitian ini bertujuan untuk mengetahui implementasi, capaian, kendala, dan solusi dari program Polisi Sekolah demi peningkatan kedisiplinan siswa di SMP Negeri 02 Arjasa Jember. Data dikumpulkan melalui wawancara, observasi, dan dokumentasi. Analisis data dilakukan dengan pendekatan deskriptif kualitatif dan juga metode analisis SWOT. Berdasarkan analisis SWOT, kedisiplinan merupakan hal yang sangat krusial dan menjadi kelemahan di SMP Negeri 02 Arjasa Jember. Salah satu strategi WO (Weakness - Opportunity) yang dapat diterapkan yaitu berupa implementasi program kegiatan terpadu untuk meningkatkan kedisiplinan di sekolah, yaitu melalui program Polisi Sekolah. Hasil penelitian menunjukkan bahwa terdapat beberapa perubahan positif yang dirasakan setelah implementasi program Polisi Sekolah. Secara umum, program Polisi Sekolah sebagai salah satu pendidikan karakter ini merupakan salah satu bukti nyata bahwa kedisiplinan di lingkungan sekolah dapat diwujudkan sebagai salah satu cara untuk meningkatkan prestasi siswa
\end{abstract}

Kata Kunci: latihan terbaik, disiplin, Polisi Sekolah

\begin{abstract}
Discipline in schools can be improved through character education, one of which is by implementing the School Police program. This study aimed to determine the implementation, achievements, constraints, and solutions of the School Police program in order to increase the student discipline in State Junior High School 02 Arjasa Jember. Data were collected by interview, observation, and documentation. Data analysis were conducted by descriptive qualitative methods and also SWOT analysis method. Based on the SWOT analysis, discipline was a very crucial thing and become one of the weakness in State Junior High School 02 Arjasa Jember. One of the WO (Weakness - Opportunity) strategies that can be implemented was in the form of implementing an integrated activity program to improve discipline in schools, namely through the School Police program. The results showed that there were some positive changes after the implementation of the School Police program. In general, the results of the study show that the Police School program, as one of character education, is one of the concrete proofs that discipline in the school environment can be realised as a way to improve student achievement.
\end{abstract}

Keywords: best practice, discipline, school police

\section{PENDAHULUAN}

Keberhasilan suatu pembelajaran salah satunya ditentukan oleh kualitas metode pembelajaran yang diterapkan oleh guru kepada siswa. Guru juga memegang peranan penting dalam mendidik dan membimbing siswa di sekolah. Berdasarkan definisinya, guru adalah pendidik profesional dengan tugas utama mendidik, mengajar, membimbing, mengarahkan, melatih, menilai, dan mengevaluasi peserta didik pada pendidikan anak usia dini jalur pendidikan formal, pendidikan dasar, dan pendidikan menengah (Alawiyah, 2016)Sedangkan menurut (Jihad, 2013), profesi guru tidak lebih dari mendidik yang bermuatan bimbingan, binaan, asuhan, ataupun pengajaran. Berdasarkan pengertian tersebut, maka secara umum guru berkewajiban memberikan yang terbaik bagi para siswanya.

Selain guru, kepala sekolah merupakan salah satu komponen pendidikan yang paling berperan dalam meningkatkan kualitas pendidikan di dunia persekolahan. Pasal 12 ayat (1) Peraturan Pemerintah Nomor 28 tahun 1990 dan ketentuan lainnya seperti Permendiknas Nomor 13 Tahun 2007 tentang Kompetensi Kepala Sekolah pada intinya menyatakan antara lain (Pendidikan, 2005), "Kepala sekolah bertanggung jawab atas penyelenggaraan kegiatan pendidikan, administrasi sekolah, pembinaan tenaga kependidikan lainnya dan pendayagunaan serta pemeliharaan sarana dan prasarana". Hal ini menjadi lebih penting sejalan dengan semakin kompleksnya tuntutan tugas kepala sekolah yang menghendaki dukungan kerja yang efektif dan efisien. Tidak hanya kepala sekolah, guru 
pun sangat berperan dalam keberhasilan suksesnya kegiatan pembelajaran di sekolah.

Sebagai kepala sekolah, penulis memiliki tekad untuk menjadikan SMP Negeri 02 Arjasa lebih maju dan bahkan bisa menjadi sekolah rujukan Kecamatan Arjasa pada umumnya. Pada awal masa tugas penulis sebagai kepala sekolah, SMP Negeri 02 Arjasa kurang populer di Kecamatan Arjasa karena minimnya prestasi, sebenarnya sudah memiliki banyak peluang untuk berkembang dan maju. Banyak potensi sekolah yang dapat dijadikan sebagai modal untuk berkembang menjadi sekolah yang responsive perubahan. Masalahnya, banyak hal yang selama ini belum dilakukan. Penyebab utamanya adalah belum adanya sarana belajar yang efektif untuk meningkatkan prestasi sekolah. Motivasi siswa maupun guru terbilang masih rendah karena guru hanya mengajar tidak termotivasi untuk membangun. Sedangkan siswa maupun orang tua belum termotivasi untuk berprestasi karena hanya bertujuan untuk menyelesaikan sekolah dasar saja. Sebagian dari orang tua justru memilih agar putra-putrinya membantu bekerja mencari nafkah setelah tamat sekolah dasar. Dalam hal kegiatan pembelajaran di sekolah, kendala yang dihadapi SMP Negeri 02 Arjasa yaitu kurangnya kesadaran para siswa akan sikap kedisiplinan dan cenderung menyepelekan sekolah, padahal sekolah sangat krusial bagi masa depan mereka.

Secara geografis letak SMP Negeri 02 Arjasa berada di daerah dataran tinggi, tepatnya bukit Rembangan, Kabupaten Jember. Untuk mencapai sekolah ini, umumnya harus menempuh jalan yang menanjak sekitar 15 kilometer dari pusat kota. Lebih lanjut lagi, SMP Negeri 02 Arjasa mempunyai sebagian besar siswa dengan latar belakang wali murid bermata pencaharian sebagai petani dan buruh kasar. Umumnya wali murid berasal dari kelas ekonomi menengah ke bawah, bahkan dapat dikatakan kesulitan secara ekonomi. Sebagian besar siswa dan wali murid umumnya kurang memiliki semangat untuk melanjutkan sekolah sehingga tidak jarang para siswa lebih memilih untuk membolos sekolah ataupun mengikuti orang tua bekerja mencari penghasilan. Berdasarkan latar belakang tersebut, banyak siswa yang terkesan menomorduakan sekolah sehingga akhirnya ketika berada di sekolah para siswa menjadi kurang disiplin dalam berbagai hal.

Dilihat dari definisinya, disiplin adalah suatu ketaatan yang sungguh-sungguh yang didukung oleh kesadaran untuk menunaikan tugas dan kewajiban serta berperilaku sebagaimana mestinya menurut aturan-aturan atau tata kelakuan yang seharusnya berlaku di dalam suatu lingkungan tertentu. Tujuan dari disiplin itu sendiri adalah untuk memberitahukan kepada anak-anak perilaku mana yang baik dan mana yang buruk, serta mendorong untuk berperilaku sesuai dengan standar-standar (Hurlock, 1990)
Lebih lanjut lagi, Permendiknas No. 39 tahun 2008 (No, 39AD) tentang pembinaan siswa menyebutkan beberapa tujuan dalam pembinaan peserta didik, salah satunya yaitu, memantapkan kepribadian peserta didik untuk mewujudkan ketahanan sekolah sebagai lingkungan pendidikan sehingga terhindar dari usaha dan pengaruh negatif yang bertentangan dengan tujuan pendidikan (Aqib, 2011)

Sekolah diharapkan memiliki program - program atau kegiatan yang dapat menjadikan peserta didik memiliki kompetensi dan mampu bersaing atau berprestasi maksimal, baik dalam bidang akademik maupun nonakademik, serta dapat mengembangkan karakter, kepribadian, dan kedisiplinan peserta didik. Sekolah sebagai sebuah institusi pendidikan bukan lagi hanya bertindak sebagai tempat untuk mentransfer ilmu saja, tetapi juga untuk membentuk sikap, perilaku karakter, dan kepemimpinan anak muda. Penelitian yang dilakukan oleh (Rokhman, Hum, \& Syaifudin, 2014) menyatakan bahwa merupakan hal yang benar untuk mencerminkan nilai dasar dan karakter Indonesia dan mengolahnya untuk generasi muda dalam bentuk pembangunan karakter nasional melalui pendidikan demi masa depan bangsa yang lebih baik.

Pendidikan karakter dapat dilakukan untuk meningkatkan kedisiplinan di sekolah. Pendidikan karakter merupakan hal yang sangat penting karena karakter mempengaruhi cara hidup seseorang dalam pengambilan keputusan untuk menjalankan kehidupannya (Setiawan, 2013) Sejalan dengan penelitian tersebut, Zamroni (Saifulloh, Muhibbin, \& Hermanto, 2012) menjelaskan bahwa pendidikan karakter berkaitan dengan pedoman kehidupan sehari-hari yang dibutuhkan untuk membuat keputusan dan menyelesaikan masalah yang dihadapi. Lebih lanjut lagi, (Handayani \& Indartono, 2016) menyatakan bahwa budaya sekolah yang positif harus dilakukan dengan memberdayakan semua anggota sekolah. Hal ini juga menjadi salah satu komponen penting yang mempengaruhi keberhasilan implementasi pendidikan karakter.

Salah satu bentuk pendidikan karakter untuk meningkatkan kedisiplinan siswa yaitu melalui penerapan program pengawasan dari murid kepada murid di sekolah, atau dalam hal ini disebut polisi anak atau Polisi Sekolah. Berdasarkan beberapa penelitian terdahulu, dikatakan bahwa penerapan program ini dapat memperbaiki karakter siswa yang cenderung kurang disiplin. Hasil penelitian (Amalia, Sari, Rahinosiwi, \& Susilowati, 2017) menyatakan bahwa pelaksanaan pendidikan karakter melalui penerapan program polisi anak di sekolah terbukti efektif diterapkan di lingkungan sekolah dasar dan secara umum dapat menumbuhkan karakter positif siswa. Penelitian yang sejalan juga dilakukan oleh Armin dan 
(Armin, n.d.) yang meneliti program Polisi Cilik sebagai kegiatan ekstrakurikuler. Hasilnya, terdapat beberapa karakter positif yang terbentuk melalui penerapan Polisi Cilik, yaitu karakter religious, jujur, disiplin, kerja keras, bertanggung jawab, peduli lingkungan sosial, serta mandiri. Dari kedua penelitian tersebut, dapat dikatakan bahwa program Polisi Cilik atau Polisi Sekolah efektif untuk diterapkan dalam hal peningkatan kedisiplinan demi keberhasilan pembelajaran di sekolah.

Namun, perlu diperhatikan juga bahwa selain siswa, karakter juga sangat diperlukan bagi seorang guru karena melalui karakter ini, para guru akan memiliki pekerjaan yang lebih efisien, berorientasi, kreatif, inovatif, produktif, dan mandiri (Suyitno, 2012) (Irhami, Supriyanto, \& Sumarsono, 2018) dalam penelitiannya mengatakan bahwa kepribadian kepala sekolah turut mempengaruhi pencapaian prestasi, misalnya kepribadian suka berkompetisi, kepercayaan dari pihak lain, serta kebiasaan berbagi ilmu dan mengikuti organisasi, serta melakukan penelitian Best practice.

Best practice (latihan terbaik) merupakan salah satu cara untuk meningkatkan keberhasilan pembelajaran ataupun perbaikan kualitas sekolah oleh kepala sekolah ataupun guru sebagai tenaga pendidik di sekolah. (Saroni, 2013)menyatakan bahwa kegiatan best practice diselenggarakan oleh satuan pendidikan dan pembelajaran sebagai upaya untuk mendidik anak agar tumbuh menjadi pribadi yang berbudi pekerti luhur. Best practice tidak hanya sebuah kegiatan teoretis dalam proses pendidikan dan pembelajaran. Kegiatan ini diutamakan pada kegiatan aktif, artinya seluruh warga sekolah harus aktif melaksanakan kegiatan ini.

Penelitian mengenai best practice terkait pendidikan karakter, peningkatan kedisiplinan, serta peningkatan prestasi siswa telah banyak dilakukan. (Samawi, Arafiq, \& Hidayah, 2014)) mengambil tema best practice mengenai model pendidikan karakter yang baik di tingkat sekolah dasar. Istanto

Best practice di SMP Negeri 02 Arjasa perlu dilakukan mengingat kondisi siswa terkait kedisiplinan masih dirasa sangat rendah. Hal ini dikhawatirkan dapat menjadi penghalang bagi suksesnya kegiatan pembelajaran di sekolah. Selain itu, dikhawatirkan sikap tidak disiplin ini akan menjadi budaya dan tertanam pada siswa, yang pada akhirnya akan berdampak buruk pada masa depan para siswa. Lebih lanjut lagi, program Polisi Sekolah masih jarang diangkat sebagai tema pada penelitian berbasis Best Practice di tingkat SMP. Oleh karena itu, penulis mengambil tema Implementasi program Polisi Sekolah untuk meningkatkan kedisiplinan di SMP Negeri 02 Arjasa Jember.

Adapun tujuan dari penelitian ini adalah untuk memberikan gambaran tentang implementasi dan capaian program Polisi Sekolah yang telah diterapkan di SMP Negeri 02 Arjasa Jember. Selain itu, penelitian ini juga bertujuan untuk mengetahui kendala dan solusi dalam implementasi program Polisi Sekolah. Penerapan Polisi Sekolah diharapkan dapat membantu mengatasi permasalahan terkait kedisiplinan siswa. Oleh karena itu, untuk mendukung hasil best practice yang telah dilakukan, artikel ini disusun agar dapat menjadi salah satu masukan bagi para kepala sekolah dalam meningkatkan kinerja sekolahnya.

Untuk mempermudah analisis, penelitian ini menggunakan metode SWOT untuk mengidentifikasi lebih detail mengenai strategi yang dapat dilakukan berdasarkan penjabaran empat poin penting yaitu kekuatan, kelemahan, kesempatan, dan ancaman. Penerapan analisis SWOT untuk menganalisis lembaga pendidikan seperti madrasah Islami telah dilakukan oleh Hadi (2013) yang menyatakan bahwa analisis SWOT sangat efektif diterapkan untuk menghasilkan upaya apa saja yang harus diambil dalam menyikapi berbagai permasalahan dilihat dari kekuatan, kelemahan, kesempatan, dan ancaman yang dimiliki.

\section{METODE}

Penelitian ini menggunakan pendekatan penelitian kualitatif. Penelitian kualitatif adalah penelitian yang bermaksud untuk memahami fenomena tentang apa yang dialami oleh subjek penelitian misalnya perilaku, persepsi, motivasi, tindakan dan lain lain, secara holistik, dan dengan cara deskriptif dalam bentuk kata-kata dan bahasa, pada suatu konteks khusus yang alamiah dengan memanfaatkan berbagai metode ilmiah (Lexy, 2002)

Pada penelitian ini, siswa kelas VII, VIII, dan IX tahun ajaran 2017/2018 bertindak sebagai sumber data primer. Data sekunder yang digunakan bersumber dari literatur, jurnal dan buku, serta sumber lain yang relevan. Data dikumpulkan melalui wawancara, observasi, dan dokumentasi. Penulis melakukan observasi dengan alasan untuk menyajikan gambaran realistik perilaku atau kejadian, untuk menjawab pertanyaan, untuk evaluasi, serta untuk melakukan pengukuran terhadapaspek tertentu serta melakukan umpan balik terhadap pengukuran tersebut (Darmadi, 2014)

Teknik analisis data yang digunakan dari model Miles and Huberman yaitu analisis model interaktif (Interactive Model of Analysis). Miles and Huberman (Ulfatin, 2013)mengemukakan bahwa aktivitas dalam analisis data kualitatif dilakukan secara interaktif dan berlangsung secara terus menerus sampai tuntas, sehingga datanya sudah jenuh. Analisis model interaktif dilakukan melalui beberapa tahap berikut yaitu periode pengumpulan data, reduksi data dengan memilih hal-hal yang pokok dan memfokuskan pada hal-hal yang penting, display data 
untuk memahami apa yang terjadi serta merencanakan kerja selanjutnya, serta penarikan kesimpulan yaitu tahap akhir dari mulai tahap awal sampai selesai sehingga mendapatkan hasil yang diinginkan dan hasil yang didapatkan dari lapangan.

Selain itu, digunakan pula analisis SWOT yang merupakan suatu alat perencanaan strategi yang penting untuk membantu perencana membandingkan kekuatan dan kelemahan internal organisasi dengan kesempatan dan ancaman dari eksternal (David L. Kurtz, 2008) Analisis SWOT dilakukan dengan identifikasi berbagai faktor secara sistematis untuk merumuskan strategi perusahaan (Rangkuti, 2001)Analisis SWOT dalam penelitian ini dimaksudkan untuk mengetahui identifikasi kekuatan kekuatan, kelemahan- kelamahan, peluang dan ancaman. Analisis ini menitikberatkan pada kondisi internal (Strengths dan Weakness) serta eksternal organisasi (Opportunities dan Threats).

\section{HASIL DAN PEMBAHASAN}

\section{Temuan Penelitian}

Untuk mengetahui kondisi awal terkait kedisipilinan di SMP Negeri 02 Arjasa, hal yang penulis lakukan adalah melakukan observasi terhadap berbagai hal untuk mendapatkan data awal sekaligus mengenal lebih jauh tentang kondisi kedisiplinan siswa di sekolah. Observasi dilakukan pada siswa kelas VII, VIII, IX yang dianggap representatif untuk mengukur tingkat kedisiplinan siswa. Hal ini dikarenakan banyak siswa membolos dan dapat dikatakan memiliki tingkat kedisipilinan yang rendah. Hasil observasi secara keseluruhan mengenai kedisiplinan siswa sebelum penerapan program Polisi Sekolah ditunjukkan pada Tabel 1.

Tabel 1. Hasil Observasi terhadap Kedisiplinan Siswa

Perihal Hasil Observasi

Kedisiplinan Sebagian besar siswa kurang rapi dalam pemakaian pemakaian atribut sekolah, misalnya atribut siswa tidak memakai dasi ke sekolah, ataupun tidak memakai topi saat upacara hari Senin.

Kedisiplinan Banyak siswa bermain - main di luar waktu area sekolah sebelum jam pelajaran dimulai, dan banyak yang berakhir dengan membolos sekolah. Siswa kurang disiplin kemungkinan karena kurangnya kegiatan di awal waktu sebelum pelajaran dimulai.

Kebersihan Kebersihan lingkungan sekolah kurang lingkungan terjaga. Hal ini ditunjukkan dengan masih banyaknya siswa yang membuang sampah sembarangan.

\begin{tabular}{ll}
\hline \multicolumn{1}{c}{ Perihal } & \multicolumn{2}{c}{ Hasil Observasi } \\
\hline Perilaku & $\begin{array}{l}\text { Terdapat beberapa siswa yang berbicara } \\
\text { kurang sopan kepada temannya, } \\
\text { sehingga terkadang menimbulkan perang } \\
\text { mulut antar sesama siswa. }\end{array}$ \\
Prestasi siswa & $\begin{array}{l}\text { Prestasi siswa di bidang akademis } \\
\text { cenderung lemah, diduga karena } \\
\text { kurangnya kedisiplinan siswa. }\end{array}$ \\
\hline
\end{tabular}

Gambar $1-3$ berikut ini merupakan dokumentasi temuan penelitian berupa kondisi sebelum penerapan Program Polisi Sekolah:

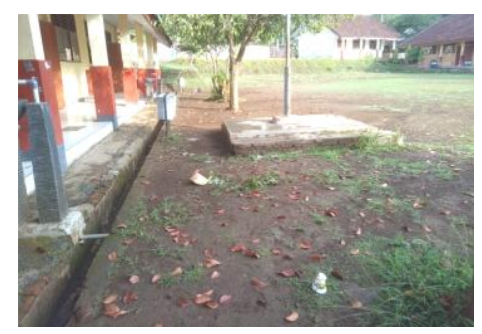

Gambar 1. Kebersihan Halaman Sekolah Kurang Terjaga

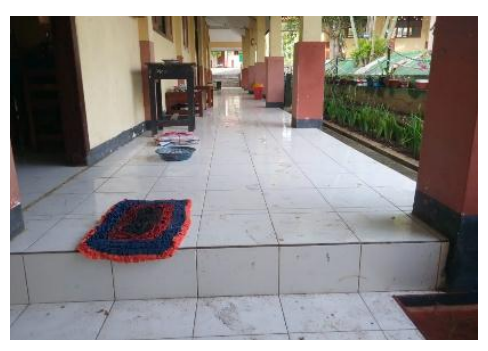

Gambar 2. Koridor Di Depan Kelas Kotor Karena Piket Kebersihan Kelas Tidak Terawasi

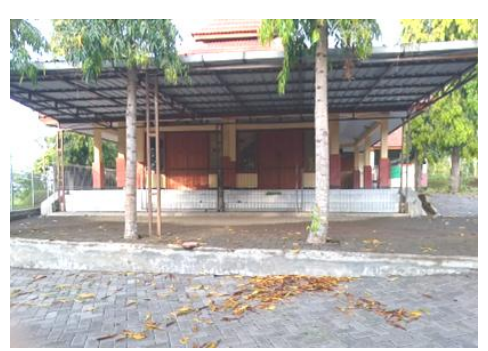

Gambar 3. Kebersihan Lingkungan Sekitar Mushola Kurang Terjaga

\section{Analisis SWOT}

Tabel 2 merupakan matriks SWOT sebagai hasil analisis dan identifikasi yang telah dilakukan. Kolom yang diberi warna menunjukkan strategi yang dapat ditempuh terkait analisis SWOT yang telah diidentifikasi. 


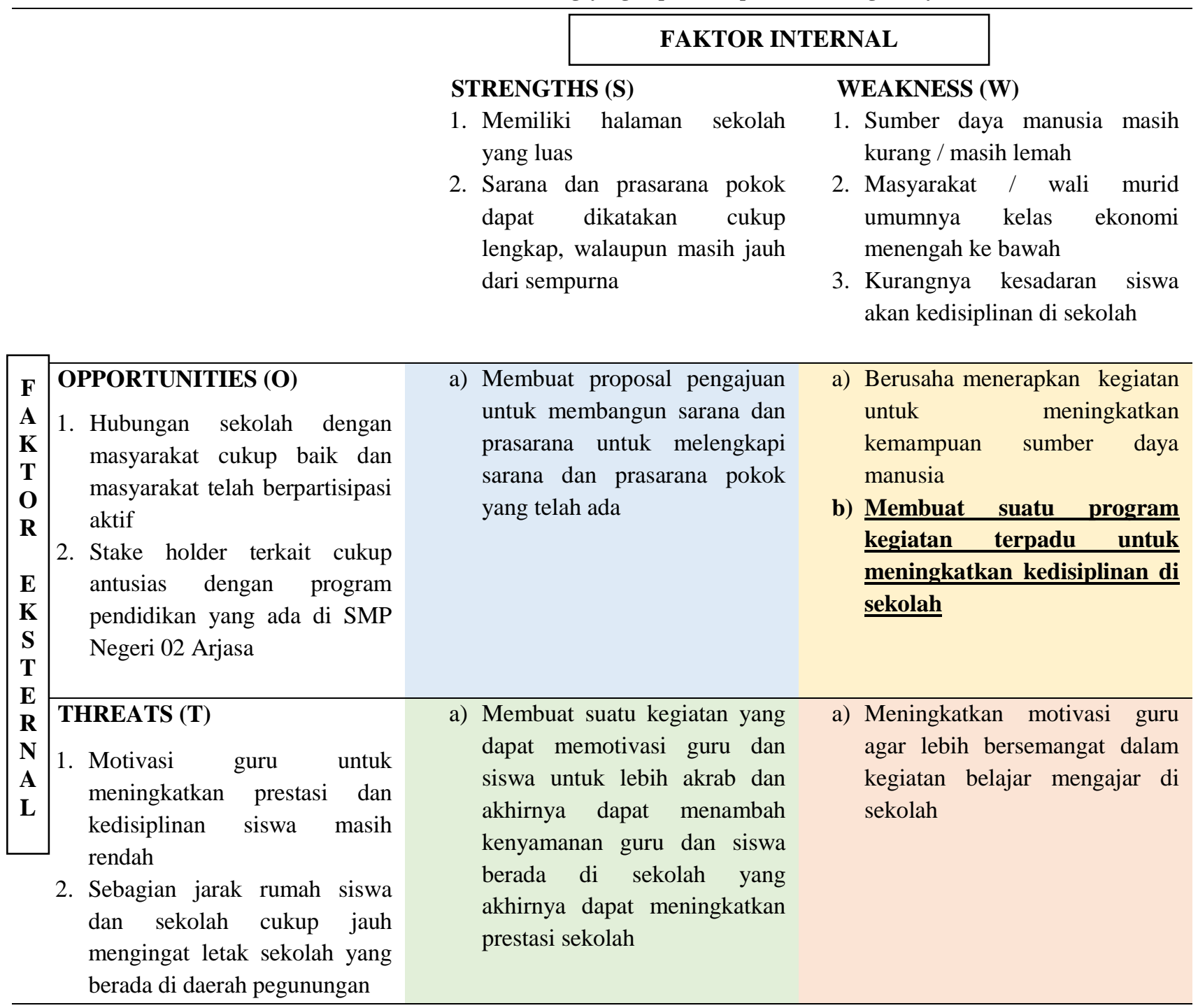

Berdasarkan hasil analisis SWOT pada Tabel 2, kelemahan yang dimiliki oleh SMP Negeri 02 Arjasa adalah lemahnya sumber daya manusia, tingkat ekonomi orang tua siswa umumnya menengah ke bawah, serta kurangnya kesadaran siswa akan kedisiplinan di sekolah. Salah satu strategi WO (Weakness - Opportunity) adalah dengan berusaha menerapkan kegiatan untuk meningkatkan kemampuan sumber daya manusia serta membuat suatu program kegiatan terpadu untuk meningkatkan kedisiplinan di sekolah. Kurangnya kesadaran akan kedisiplinan menjadi topik utama yang sekaligus menjadi masalah krusial di SMP Negeri 02 Arjasa, sehingga memerlukan penanganan yang lebih serius.

\section{Implementasi Program Polisi Sekolah}

Program Polisi Sekolah bermula dicanangkan pada awal tahun 2017, namun pada awal implementasinya masih secara tidak resmi, hanya melalui pemilihan anggota secara lisan, tanpa adanya susunan kepengurusan. Sekitar akhir tahun 2017, program Polisi Sekolah mendapat perhatian serius dari seluruh warga sekolah, karena terbukti dapat meningkatkan kedisiplinan siswa. Program Polisi Sekolah ini dicanangkan di SMP Negeri 02 Arjasa dengan melibatkan guru dan siswa yang memiliki prestasi akademik 10 besar di kelasnya. Siswa mendapatkan pelatihan seperti Latihan Dasar Kepemimpinan dan Latihan Baris - berbaris setiap minggunya. 
Program Polisi Sekolah tidak hanya bertujuan untuk melatih kedisiplinan siswa, tetapi juga untuk melatih tanggung jawab siswa, dan melatih mental para siswa jika nantinya mereka terjun ke dunia kerja, serta meningkatkan pertahanan sekolah terhadap ancaman-ancaman yang berasal dari lingkungan luar sekolah. Program Polisi Sekolah yang diimplementasikan di SMP Negeri 02 Arjasa, Jember bukan berupa kegiatan Ekstrakurikuler, namun lebih mengarah pada organisasi yang dibimbing oleh guru dengan pengawasan dari Kepala Sekolah. Program kegiatan Polisi Sekolah merupakan kegiatan penunjang, akan tetapi dilakukan secara rutin.

Pemilihan anggota Polisi Sekolah dilakukan setahun sekali setelah kenaikan kelas. Adapun urutan pembentukan pemilihan anggota adalah sebagai berikut:

1. Masing - masing kelas mengirimkan wakilnya sebanyak 4 orang untuk melakukan seleksi

2. Siswa yang mengikuti seleksi diwajibkan menduduki peringkat 10 besar di kelas

3. Seluruh calon anggota Polisi Sekolah diseleksi terkait kemampuan, integritas, dan tanggung jawab
4. Dari setiap kelas akan terpilih 2 orang terbaik sebagai Polisi Sekolah untuk ditugaskan di kelasnya masing masing

5. Dilakukan pengukuhan sebagai anggota Polisi Sekolah

6. Diberikan pelatihan mengenai kedispilinan dan tanggung jawab

7. Anggota Polisi Sekolah mulai bertugas sesuai dengan arahan dari guru

8. Seluruh anggota wajib mengikuti pelatihan - pelatihan rutin yang diselenggarakan oleh sekolah

9. Apabila terdapat pelanggaran - pelanggaran yang dilakukan oleh Polisi Sekolah, maka jabatannya sebagai Polisi Sekolah dapat dihentikan dan digantikan oleh siswa lain yang pernah mengikuti seleksi.

Adapun program kegiatan Polisi Sekolah ini meliputi kegiatan sebelum masuk ke kelas, sebelum pelajaran dimulai, saat jam pelajaran, saat jam istirahat, serta sebelum pulang (Tabel 3). Kegiatan program Polisi Sekolah yang sudah berjalan juga didokumentasikan untuk meilhat sejauh mana keberhasilan program tersebut serta sebagai bahan evaluasi untuk meningkatkan capaian suatu program ke depannya.

Tabel 3. Program Kegiatan Polisi Sekolah

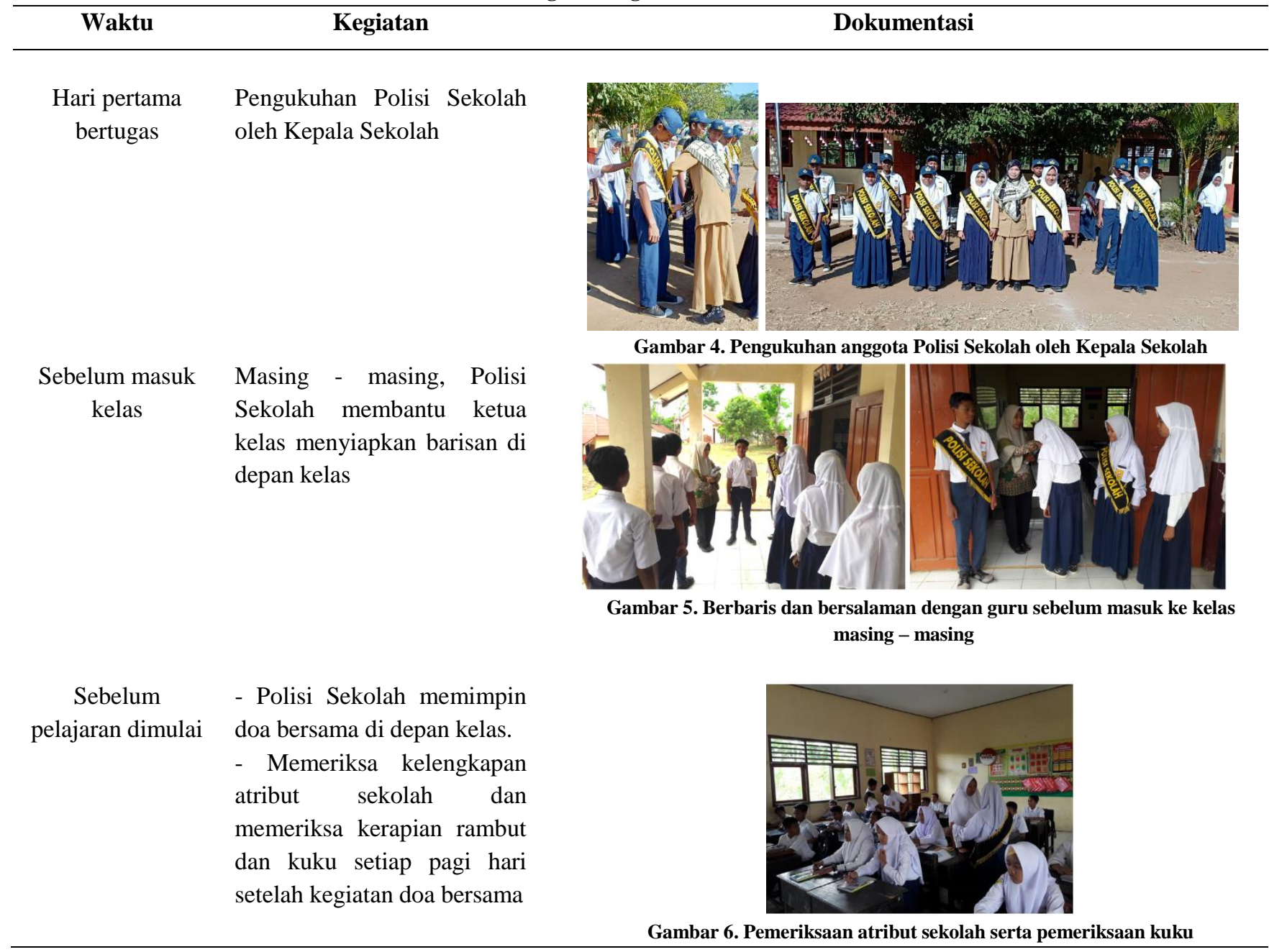




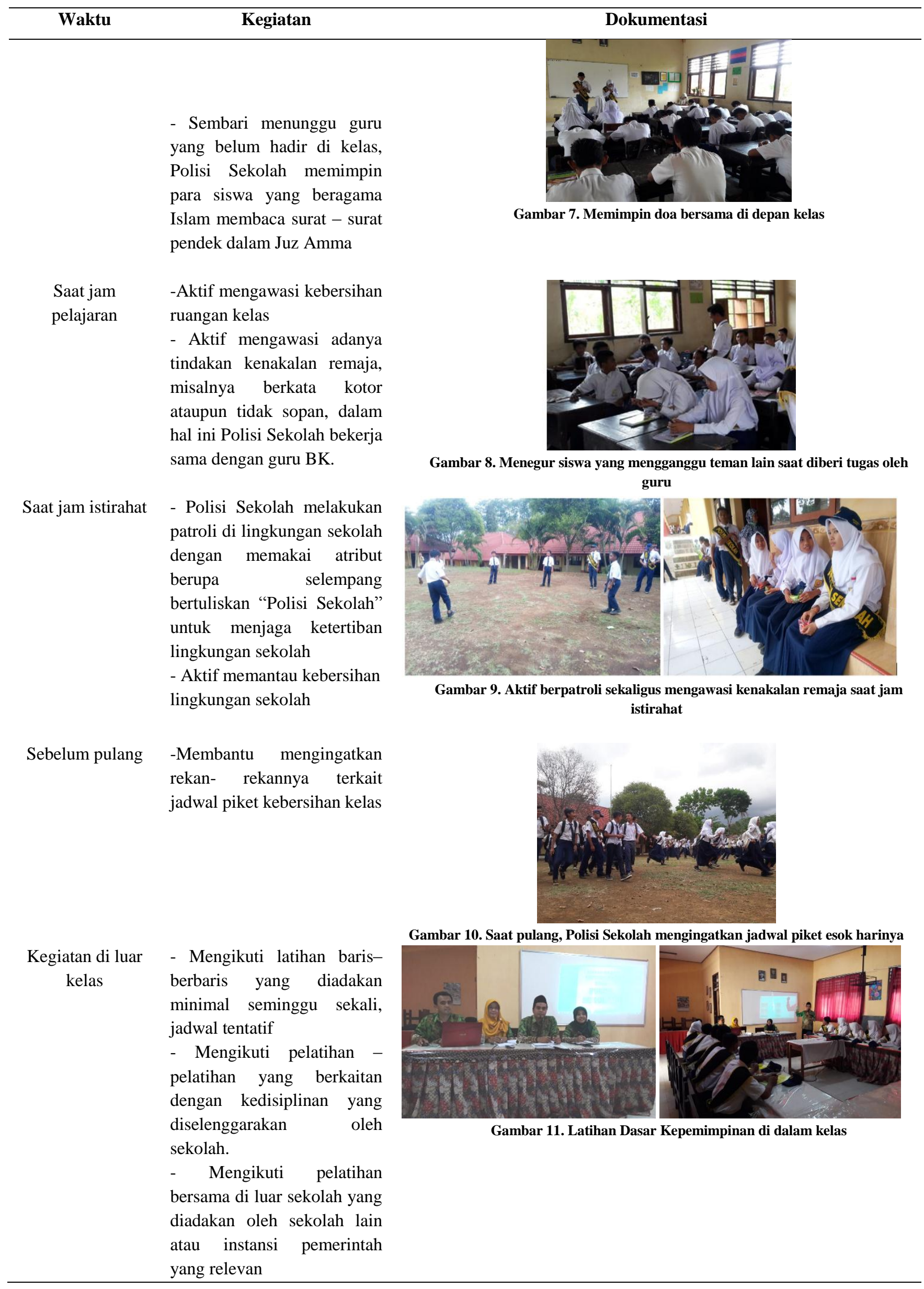




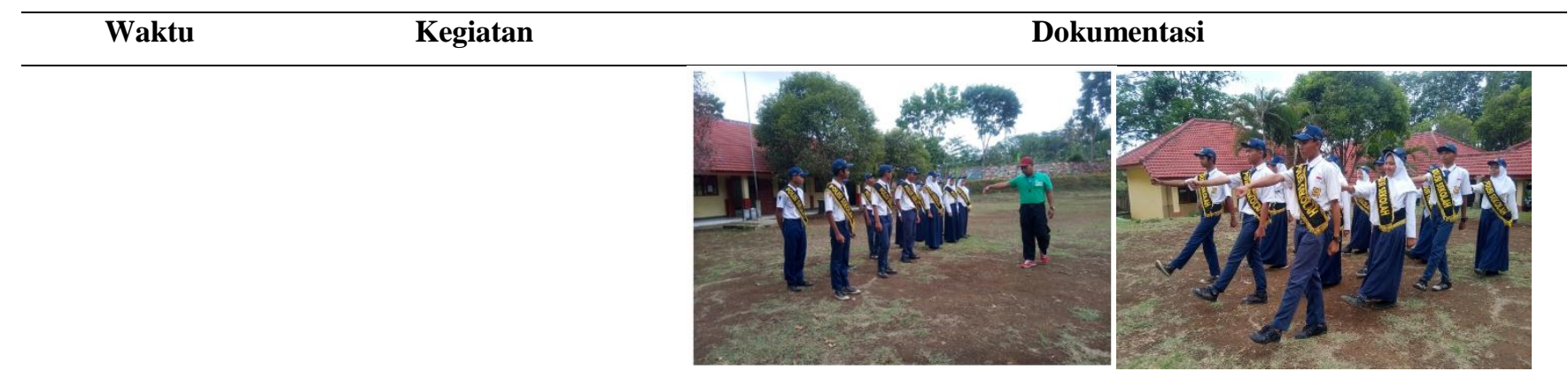

Gambar 12. Latihan Dasar Kepemimpinan di luar kelas

\section{Capaian Setelah Penerapan Program Polisi Sekolah}

Selama kurang lebih dua tahun dilakukan implementasi Program Polisi Sekolah, maka beberapa indikator keunggulan yang saat ini telah dimiliki oleh SMP Negeri 02 Arjasa antara lain:

\section{Peningkatan Kebersihan Sekolah}

Setelah mengimplementasikan program Polisi Sekolah, yang paling nyata terlihat adalah perihal kebersihan lingkungan sekolah yang mengalami peningkatan. Hal ini salah satunya dikarenakan aktifnya piket kelas dan kegiatan Jumat bersih dengan pengawasan aktif oleh Polisi Sekolah. Siswa yang tidak melaksanakan piket kelas harian akan dicatat oleh Polisi Sekolah, dilaporkan pada wali kelas, dan akan diberikan hukuman disiplin sesuai kebijakan wali kelas.

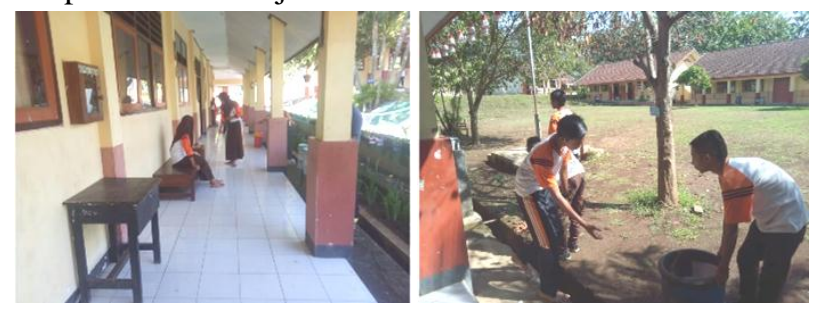

Gambar 13. Jadwal piket berjalan dengan baik karena pengawasan Polisi Sekolah

Melalui penerapan jadwal piket yang diawasi oleh Polisi Sekolah, maka siswa menjadi lebih bertanggung jawab terhadap kebersihan kelasnya masing - masing dan akhirnya lingkungan sekolah menjadi lebih bersih. Dengan lingkungan yang bersih, maka kegiatan belajar mengajar di sekolah menjadi lebih nyaman.

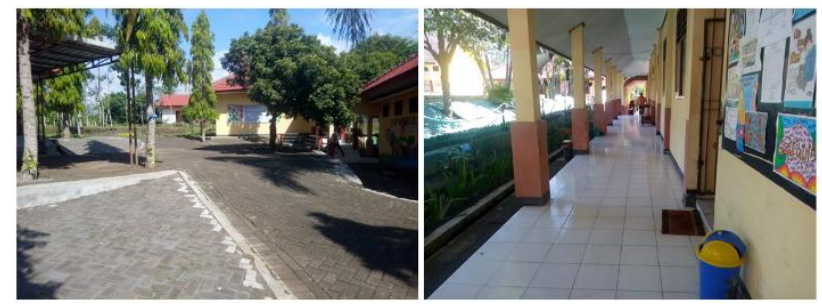

Gambar 14. Lingkungan sekolah dan koridor kelas menjadi lebih bersih

\section{Penurunan Jumlah Siswa yang Membolos}

Hasil observasi awal sebelum implementasi program Polisi Sekolah menunjukkan bahwa jumlah siswa yang membolos / tidak masuk kelas tanpa izin mengalami penurunan sebanyak $27 \%$. Setelah implementasi program Polisi Sekolah, siswa -siswi menjadi lebih patuh dan taat terhadap tata tertib yang diberikan sekolah, termasuk mengenai larangan membolos ataupun tidak masuk kelas tanpa izin.

\section{Peningkatan Ketertiban Siswa}

Melalui penerapan program Polisi Sekolah, hampir tidak ada siswa- siswi yang berkeliaran di sekitar koridor saat pergantian jam pelajaran ataupun saat jam kosong dan sedang menanti guru pengganti, sehingga suasana sekolah menjadi semakin tertib. Selain itu, adanya peraturan yang diikuti dengan pengawasan langsung dari Polisi Sekolah secara umum membuat suasana sekolah menjadi semakin tertib.

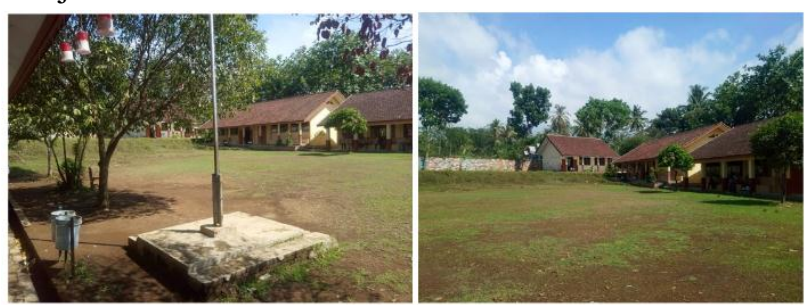

Gambar 15. Tidak ada siswa berkeliaran di luar kelas ketika pergantian jam pelajaran

\section{Perubahan Suasana Sekolah menjadi Lebih Agamis}

Siswa - siswi yang beragama Islam diwajibkan untuk membaca surat - surat pendek dalam Juz Amma dipimpin oleh Polisi Sekolah sembari menanti guru datang ke kelas. Sebelum pelajaran pertama dimulai, Polisi Sekolah juga diwajibkan untuk memimpin doa bersama. Hasil penerapan kegiatan ini secara umum diharapkan dapat meningkatkan ketakwaan siswa terhadap Tuhan YME. Selain itu, suasana sekolah menjadi lebih terkesan agamis. Hal ini menjadi poin penting di lingkungan SMP Negeri 02 Arjasa Jember, yang merupakan lingkungan pesantren, 
dan dapat dikatakan bersaing dengan madrasah madrasah yang lebih mengedepankan perihal agama.

\section{Peningkatan Prestasi Siswa}

Salah satu capaian dari meningkatnya tingkat kedisiplinan siswa dengan penerapan program Polisi Sekolah yaitu secara tidak langsung meningkatkan prestasi siswa. Hal ini dapat ditunjukkan dari meningkatnya nilai rata - rata kelas setelah penerapan dibandingkan dengan nilai rata - rata sebelum penerapan program Polisi Sekolah. Walaupun peningkatan prestasi akademik ini tidak terlalu signifikan, yaitu hanya sebesar $11 \%$, namun hal ini merupakan prestasi tersendiri bagi SMP Negeri 02 Arjasa, mengingat sumber daya manusia yang sebelumnya tidak terbiasa disiplin di sekolah dan berasal dari masyarakat ekonomi lemah.

\section{Peningkatan Kepuasan Orang Tua Siswa}

Dampak yang juga secara tidak langsung dirasakan setelah penerapan program Polisi Sekolah adalah orang tua siswa merasa puas dan senang akan meningkatnya prestasi putra putrinya di sekolah. Selain itu, ada kebanggaan tersendiri bagi orang tua yang putra putrinya terpilih sebagai Polisi Sekolah. Hal ini dikarenakan untuk menjadi seorang Polisi Sekolah terdapat beberapa syarat yang harus dipenuhi dan melalui serangkaian pelatihan. Selain itu, sebagian besar orang tua siswa umumnya merasa bahwa terdapat perubahan positif pada anaknya yaitu menjadi lebih disiplin, misalnya dalam hal menyiapkan atribut untuk upacara di hari Senin. Siswa yang biasanya tidak menyiapkan kelengkapan seragam saat upacara seperti dasi, topi, dan kaus kaki putih, kini mulai menyiapkan sendiri karena takut dihukum di sekolah. Walaupun kecil, hal ini tentunya menjadi perubahan positif yang cukup membahagiakan orang tua di rumah. Sikap disiplin ini diharapkan dapat menjadi kebiasaan yang dapat terus diterapkan dalam kehidupan sehari - hari.

\section{Kendala dan Solusi Implementasi Program Polisi Sekolah}

Dalam implementasi program Polisi Sekolah di SMP Negeri 02 Arjasa Jember ini, tentunya tidak lepas dari hambatan. Namun, harus selalu ada solusi untuk menyelesaikannya. Hambatan yang pertama yaitu masih lemahnya budaya responsif perubahan dari para guru dan warga sekolah membuat upaya pencapaian tujuan tidak selalu sesuai dengan rencana yang diharapkan. Para siswa umumnya masih terbawa oleh budaya lama, yaitu tidak disiplin. Kesulitan untuk berubah ke arah yang lebih baik ini disebabkan oleh kurangnya pembiasaan atau keteladanan dari para guru. Dalam penerapan program Polisi Sekolah, seharusnya ada pengawasan langsung dari guru selaku wali kelas, namun terkadang masih ada oknum guru yang malas dan bersikap kurang disiplin. Salah satu solusi yang dapat digunakan untuk mengatasi kendala itu adalah adanya penerapan manajemen keteladanan dari penulis selaku kepala sekolah secara intensif. Sehingga dengan begitu para guru dapat mencontoh kedisiplinan dari Kepala Sekolah dan saling mengingatkan satu sama lain. Nantinya, diharapkan para siswa dapat mencontoh sikap para guru dan akhirnya kedisiplinan dapat terjaga dengan baik. Solusi lain yang dapat diambil yaitu dengan menerapkan sistem reward and punishment, yaitu penghargaan bagi guru atau wali kelas yang program Polisi Sekolahnya paling efektif serta hukuman bagi guru atau wali kelas yang malas.

Hambatan yang kedua yaitu masih terkendalanya pencapaian dan peningkatan prestasi akademik di sekolah akibat siswa tidak terbiasa disiplin di rumah. Hal ini diduga berhubungan dengan tingkat perekonomian orang tua siswa yang masih lemah. Karena kurangnya tingkat pendidikan, sebagian besar orang tua siswa tidak menjadikan sekolah sebagai prioritas utama. Hal ini lah yang menjadikan kurangnya peningkatan kedispilinan yang berujung pada kurangnya peningkatan prestasi akademik siswa - siswi. Solusi yang dapat ditawarkan yaitu dengan perlahan - lahan menanamkan pola pikir kepada orang tua bahwa sekolah harus menjadi prioritas utama. Solusi lainnya yaitu dengan melakukan kegiatan penyuluhan pentingnya sekolah oleh penulis selaku Kepala Sekolah. Hal ini telah dilakukan yaitu dengan mengunjungi rumah warga di sekitar lingkungan sekolah untuk mensosialisasikan kegiatan sekolah dan promosi sekolah. Hal ini salah satunya dimaksudkan agar orang tua siswa yang berasal dari latar belakang pendidikan rendah, dapat memahami bahwa sekolah sangat penting bagi masa depan putra- putri mereka.

\section{PENUTUP}

\section{Simpulan}

Secara keseluruhan, terdapat beberapa perubahan positif yang dirasakan setelah implementasi program Polisi Sekolah, seperti peningkatan kebersihan sekolah, penurunan jumlah siswa yang membolos, peningkatan ketertiban siswa, perubahan suasana sekolah menjadi lebih agamis, peningkatan prestasi siswa, serta peningkatan kepuasan orang tua siswa. Secara umum, program Polisi Sekolah sebagai salah satu pendidikan karakter ini merupakan salah satu bukti nyata bahwa kedisiplinan di lingkungan sekolah dapat diwujudkan sebagai salah satu cara untuk meningkatkan prestasi siswa. Untuk itu, diperlukan kerjasama yang baik, dalam hal ini adalah kerjasama berbagai pihak yaitu kepala sekolah, guru, komite sekolah, wali murid, masyarakat lingkungan sekolah, dan bahkan stakeholder perlu diwujudkan. 


\section{Saran}

Best practice ini hanya merupakan bagian kecil dari penelitian yang telah diimplementasikan penulis di SMP Negeri 02 Arjasa Jember untuk mewujudkan kondisi sekolah efektif melalui peningkatan kedisiplinan. Penulis sadar bahwa karya ini masih jauh dari sempurna, namun penulis berharap bahwa karya ini dapat menjadi bagian dari salah satu program pendidikan untuk meningkatkan kualitas pendidikan di Indonesia pada umumnya. Berdasarkan temuan pada penelitian ini, dapat dikatakan bahwa program Polisi Sekolah dapat diimplementasikan untuk peningkatan kedisiplinan di sekolah, dan akan dapat semakin berhasil jika disertai dengan pendampingan dari pemerintah pusat terkait pendanaan untuk kegiatan pelatihan - pelatihan yang dapat dilakukan demi menunjang keberhasilan program tersebut.

\section{DAFTAR PUSTAKA}

Alawiyah, F. (2016). Peran Guru dalam Kurikulum 2013. Jurnal Aspirasi, 4(1), 65-74.

Amalia, N., Sari, N. W., Rahinosiwi, U. H. W., \& Susilowati, I. (2017). Pendidikan Karakter Melalui Program Polisi Anak Sebagai Peer Teaching di Sekolah Dasar. Prosiding Seminar Nasional Pendidikan Berkemajuan dan Menggembirakan (The ....

Aqib, Z. (2011). Panduan dan Aplikasi Pendidikan Karakter. Bandung: Yrama Widya.

Armin, D. D. (n.d.). Pembentukan Karakter Peserta Didik melalui Ekstrakurikurikuler Polisi Cilik di SDN Landungsari 1 Malang.

Darmadi, H. (2014). Metode Penelitian Pendidikan dan Sosial: Teori Konsep Dasar dan Implementasi. Bandung: Alfabeta.

David L. Kurtz. (2008). Principles of Contemporary Marketing. South Western Educational Publishing.

Handayani, N., \& Indartono, S. (2016). The Implementation of Multicultural Character Education. In ICEBESS 2016 Proceeding: International Conference on Ethics of Business, Economics, and Social Science. Available online also at: http://eprints. uny. ac. id/41853/1/41\% 20Nurlaili\% 20Handayani. pdf [accessed in Bandung, Indonesia: October 28, 2017].

Hurlock, E. B. (1990). Psikologi Perkembangan Edisi 5. Jakarta: Erlangga.

Irhami, P. I., Supriyanto, A., \& Sumarsono, R. B. (2018). Strategi Kepala Sekolah dalam Pencapaian Prestasi Terbaik pada Lomba Kepala Sekolah Berprestasi. JAMP: Jurnal Administrasi Dan Manajemen Pendidikan, 1(4), 381-387.

Jihad, A. (2013). Menjadi guru profesional: Strategi meningkatkan kualifikasi dan kualitas guru di era global. Penerbit Erlangga.

Lexy, M. (2002). Metode Penelitian Kualitatif, PT. Remaja Rosdakarya, Bandung.

No, P. (39AD). tahun 2008 Tentang Kesiswaan.

Pendidikan, B. S. N. (2005). Standar nasional pendidikan. Diakses Dari Http://Www. Bsnpindonesia. Org, Pada Tanggal, 11.

Rangkuti, F. (2001). Analisis SWOT: Teknik Membedah Kasus Bisnis. Jakarta: Gramedia Pustaka Utama.

Rokhman, F., Hum, M., \& Syaifudin, A. (2014). Character Education For Golden Generation 2045 (National Character Building for Indonesian Golden Years). Procedia-Social and Behavioral Sciences, 141, 1161-1165.

Saifulloh, M., Muhibbin, Z., \& Hermanto, H. (2012). Strategi Peningkatan Mutu Pendidikan di Sekolah. Jurnal Sosial Humaniora, 5(2), 206-218.

Samawi, A., Arafiq, M. A. M., \& Hidayah, L. (2014). Model Pendidikan Karakter yang Baik (Studi Lintas Situs Bests Practices) Pendidikan Karakter di SD. Sekolah Dasar: Kajian Teori Dan Praktik Pendidikan, 23(2).

Saroni, M. (2013). Best Practice: Langkah Efektif Meningkatkan Kualitas Karakter Warga Sekolah. Yogyakarta: Az Ruzz Media.

Setiawan, D. (2013). Peran pendidikan karakter dalam mengembangkan kecerdasan moral. Jurnal Pendidikan Karakter, (1).

Suyitno, I. (2012). Pengembangan Pendidikan Karakter dan Budaya Bangsa Berwawasan Kearifan Lokal. Jurnal Pendidikan Karakter, (1).

Ulfatin, N. (2013). Metode penelitian kualitatif di bidang pendidikan: Teori dan Aplikasinya. Malang: Bayumedia Publishing. 